\title{
THE EFFECT OF PANCURONIUM BROMIDE ON PLASMA NOR-EPINEPHRINE CONCENTRATIONS DURING KETAMINE INDUCTION
}

\author{
Akitomo Matsuki, M.D., "Elemér K. Zsigmond, M.D., " Robert C. Kelsch, M.D., \\ and Sarla P. Kothary, M.D., ${ }^{*}$ with the technical assistance of Louise VadNay $†$
}

\section{INTRODUCTION}

IT IS WELL SUBSTANTIATED that ketamine $2.0 \mathrm{mg} / \mathrm{kg}$ intravenously causes a marked rise in blood pressure, pulse rate ${ }^{1}$ and free nor-epinephrine levels in plasma. ${ }^{2}$ Since ketamine is frequently used in combination with pancuronium, which also induces tachycardia and hypertension, it is important to know the circulatory changes associated with this combination in order to use it safely. The circulatory effects of pancuronium have been shown to be due to a specific vagolytic action on the heart in mammals ${ }^{3}$ and in men. ${ }^{4}$ Indeed, the tachycardia induced by pancuronium is primarily responsible for the increase in cardiac output. ${ }^{5}$ Furthermore, we found no rise in plasma free nor-epinephrine concentration after pancuronium following thiamylal induction. ${ }^{6}$ Since thiamylal may reduce the sympathetic discharge centrally, ${ }^{\top}$ and thereby interfere with the rise of norepinephrine levels, it might mask the rise elicited by pancuronium. If indeed pancuronium causes an increase in nor-epinephrine, this effect ought to be enhanced when pancuronium is used in combination with ketamine, which also causes a marked rise in nor-epinephrine levels. Therefore, an additive effect of pancuronium with ketamine on the plasma nor-epinephrine levels was expected, with a marked rise in blood pressure and pulse rate as a null hypothesis when this study began.

\section{Materials and Methods}

Seventeen patients were studied who had been scheduled for surgery who were free of hepatic, renal and endocrine systemic diseases. They had no history of steroid therapy. Twelve patients received ketamine and five others ketamine in combination with pancuronium. The age, weight, and sex of the patients are recorded in Table I.

Preanaesthetic medication consisted of $0.15 \mathrm{mg} / \mathrm{kg}$ diazepam, $0.15 \mathrm{mg} / \mathrm{kg}$ morphine and $0.006 \mathrm{mg} / \mathrm{kg}$ atropine sulfate intramuscularly one hour prior to the start of anaesthesia. Ketamine in a dose of $2.0 \mathrm{mg} / \mathrm{kg}$ was given intravenously over a thirty second period to all patients. In the ketamine-pancuronium group, the patient also received $0.09 \mathrm{mg} / \mathrm{kg}$ pancuronium intravenously over a ten second period immediately following the ketamine injection. The timing began at the end of injection in both groups. Both groups of patients received respiratory assistance through a face mask with the combination of nitrous oxide-oxygen 4:2 $\mathrm{L} / \mathrm{min}$. We attempted to maintain the $\mathrm{PaCO}$., between $35-4.5$ torr to avoid

'Department of Anaesthesiology and tDepartment of Paediatrics, University of Michigan Medical Center, Ann Arbor, Michigan, U.S.A. 
TABLE I

Physical Characteristics of the Patients Studied

\begin{tabular}{|c|c|c|c|c|c|}
\hline \multirow{2}{*}{$\begin{array}{c}\text { Drug } \\
\text { Combination }\end{array}$} & \multirow[b]{2}{*}{$\mathrm{N}$} & \multicolumn{2}{|c|}{ Sexes } & \multirow{2}{*}{$\begin{array}{c}\text { Mean Age } \\
\text { and } \\
\text { Ranges }\end{array}$} & \multirow{2}{*}{$\begin{array}{c}\text { Mean Weight } \\
\text { in kg \& } \\
\text { Ranges }\end{array}$} \\
\hline & & Male & Female & & \\
\hline $\begin{array}{l}\text { Ketamine } \\
2.0 \mathrm{mg} / \mathrm{kg}\end{array}$ & 12 & 4 & 8 & $\begin{array}{c}50.9 \\
(30-70)\end{array}$ & $\begin{array}{c}64.6 \\
(44-82)\end{array}$ \\
\hline $\begin{array}{l}\text { Ketamine } \\
2.0 \mathrm{mg} / \mathrm{kg} \mathrm{\&} \\
\text { Pancuronium } \\
0.09 \mathrm{mg} / \mathrm{kg}\end{array}$ & 5 & 0 & 5 & $\begin{array}{c}47.6 \\
(28-68)\end{array}$ & $\begin{array}{c}69.9 \\
(49-92)\end{array}$ \\
\hline
\end{tabular}

sympathetic stimulation by hypercarbia and to maintain the oxygen saturation at 100 per cent. Those patients who showed changes outside these criteria were excluded from final evaluation. No intubation, no changes in position, and no surgical preparation were allowed. The arterial blood samples for the determination of blood gases were taken before and 2, 5, and 10 minutes following the intravenous injection of the ketamine or the ketamine-pancuronium combination through an indwelling catheter from the brachial artery. At the same time, venous blood samples were taken from the antecubital vein for determination of plasma norcpinephrine.

Plasma free nor-epinephrine concentrations were measured by Vendsalu's method as modified by Kelsch. ${ }^{8}$ Arterial blood gas analyses were performed by the Astrup method utilizing the Siggaard-Andersen nomogram. ${ }^{9}$

\section{Results}

\section{Circulatory Changes:}

The mean systolic blood pressure of the 12 patients who had received ketamine was markedly elevated $(p<0.01)$ at 2 and 5 minutes, while there was only a moderate insignificant rise $(p>0.1)$, in the five patients who had been given ketamine in combination with pancuronium, as shown in Figure 1. A significant increase $(p<0.01)$ in pulse rate was observed at 2 minutes and 5 minutes after the administration of ketamine, in contrast to the moderate and insignificant rise ( $p>0.05$ ) that followed the combination of pancuronium and ketamine, as illustrated also in Figure 1.

\section{Plasma Nor-epinephrine:}

A highly significant rise of free nor-epinephrine in plasma occurred at $5 \mathrm{~min}$ $(p<0.001)$ following the administration of ketamine as compared to base line values or to the values observed at 5 minutes following the administration of pancuronium-ketamine combination. This is shown in Figure 2. No significant rise of free nor-epinephrine levels in plasma was observed at any time following ketamine-pancuronium combination.

\section{Arterial Blood Gas Analyses:}

Analysis of arterial blood gases excluded respiratory acidosis and hypercarbia 


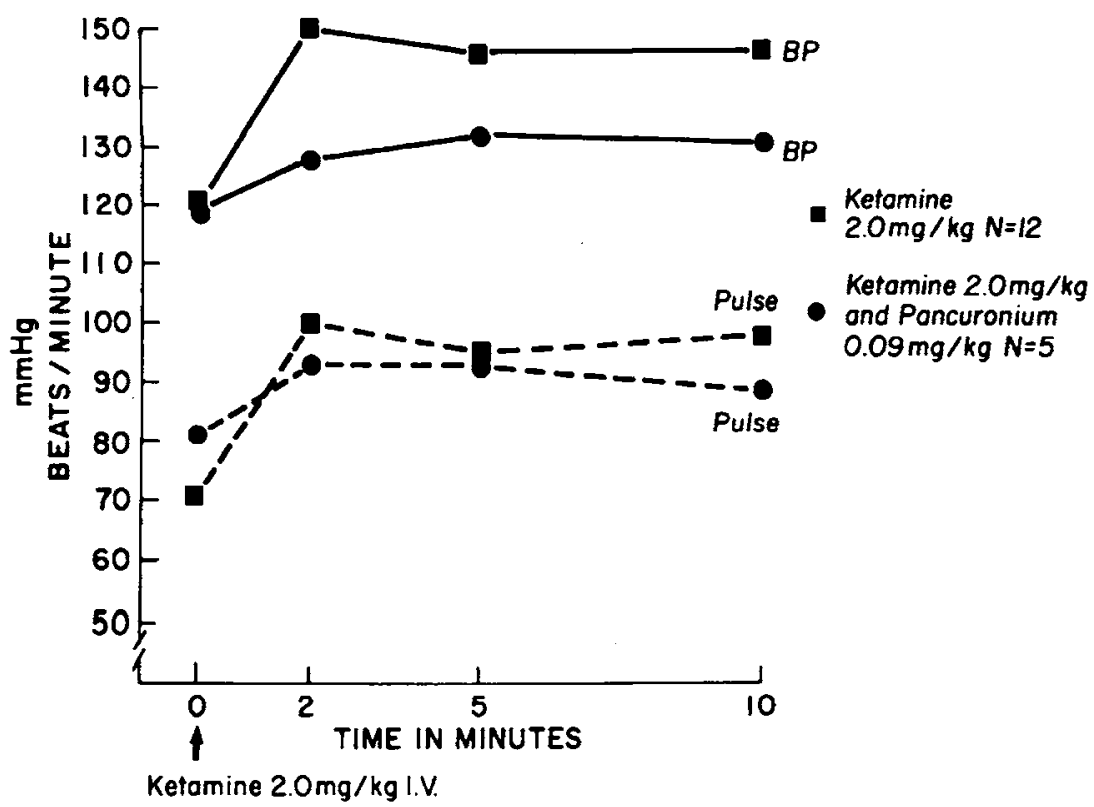

Ficure 1. The influence of pancuronium on the ketamine induced circulatory changes.

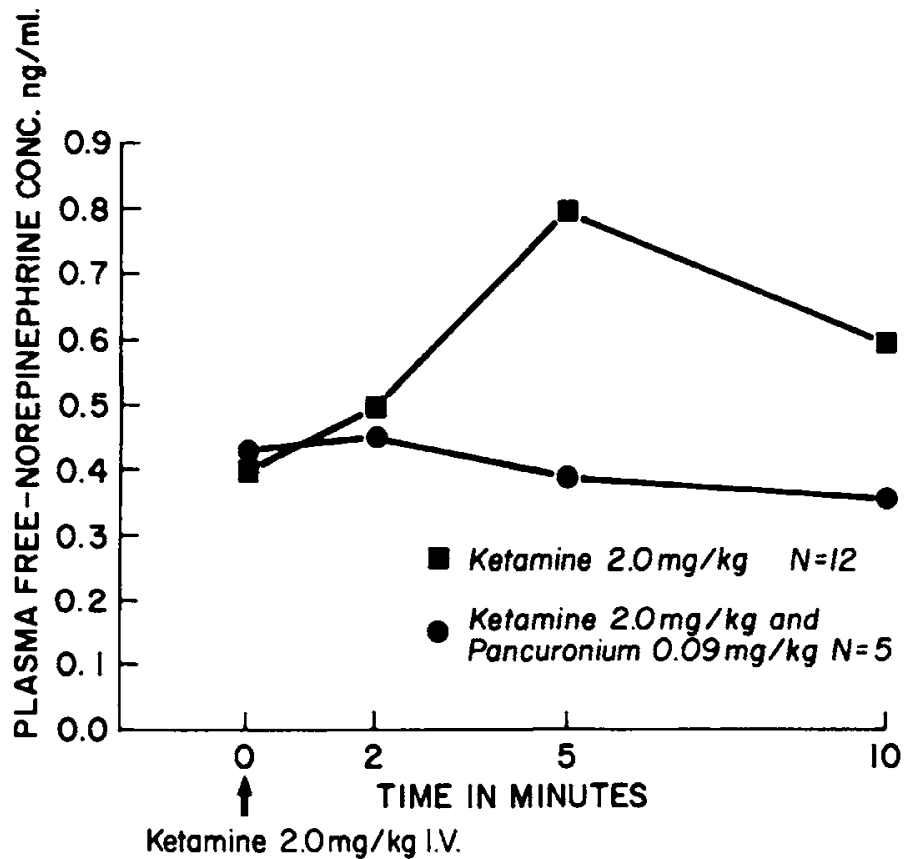

Ficure 2. The intluence of pancuronium on the rise in plasma free nor-epinephrine caused by ketamine. 
during the study. Arterial oxygen saturation remained above 90 per cent and $\mathrm{PaO}_{2}$ above $80 \mathrm{mmHg}$ following drug administration.

\section{Discussion}

Sympathetic stimulation by intravenous ketamine administration was indirectly suggested by a number of studies ${ }^{10.11,12}$ prior to our preliminary report of the markedly elevated free nor-epinephrine levels observed in plasma in this study, ${ }^{2}$ This rise in nor-epinephrine level follows the rise in blood pressure and pulse rate. It is likely that the measured plasma level of free nor-epinephrine represents the overflow of nor-epinephrine which is not taken up or metabolized at the periphery.

Although Saxena and Bonta ${ }^{3}$ claimed, from animal experiments, that the circulatory changes related to pancuronium are caused by a blockade of parasympathetic efferents in the heart, and Kelman and Kennedy ${ }^{4}$ and Gertel et al ${ }^{5}$ showed in anaesthetized man that the tachycardia caused by pancuronium is responsible for a rise in cardiac output, we still wanted to rule out the possibility that pancuronium has an influence on free nor-epinephrine levels in plasma. We previously reported that pancuronium caused no increase of free nor-epinephrine level in plasma during thiamylal induction. ${ }^{6}$ Based on the results presented, we conclude that pancuronium not only had no additive effect with ketamine on free nor-epinephrine of plasma but also prevented the rise induced by ketamine. Furthermore, pancuronium also reduced the rise in pulse rate and blood pressure. The mechanism by which pancuronium exerts this protective effect is not clear. One can only speculate that pancuronium may prevent the release of nor-epinephrine from the sympathetic storage granules in the heart by its vagolytic effect. It thus prevents access of acetylcholine, which is necessary for the release of nor-epinephrine from the storage granules. Since pancuronium is a strongly ionized compound, it is unlikely to get through the blood brain barrier to block central sympathetic stimulation. It may, however, facilitate re-uptake of norepinephrine or stabilize the nor-epincphrine storage granules, so preventing the release of nor-epinephrine.

These findings may have great clinical implications, therefore, since a ketaminepancuronium induction sequence may safely be used in poor risk patients in whom circulatory changes should be avoided. The indications for ketamine can also be extended to patients in whom tachycardia and hypertension may have adverse effects.

These unexpected findings with the pancuronium-ketamine combination will require further confirmation. The results of studies in a few anaesthetized with this induction sequence were encouraging since no changes in the directly recorded arterial blood pressure, heart rate or free nor-epinephrine occurred. This might be attributed to the diazepam-morphine premedication. However the findings in the ketamine study group militate against this assumption since these patients received the same premedication as the ketamine-pancuronium group.

Further clinical and laboratory investigations are currently in progress to clarify the mechanism of the blocking effect of pancuronium on the ketamineinduced nor-epinephrine rise. 
SUMMARY

Ketamine $2.0 \mathrm{mg} / \mathrm{kg}$ alone with nitrous oxide-oxygen inhalation caused a rise in blood pressure, pulse rate and free nor-epinephrine levels in plasma in twelve elective surgical patients. Contrary to expectations, the combination of ketamine with pancuronium during nitrous oxide-oxygen inhalation caused no rise in nor-epinephrine in plasma and reduced the rise in arterial blood pressure and pulse rate. No intubation, surgical preparation, or positional changes were allowed. No hypoxia or hypercarbia was demonstrated by the blood gas studies. The mechanism of this blocking effect of pancuronium on ketamine-induced norepinephrine rise await clarification by further laboratory and clinical experiments. The combination of ketamine with pancuronium, can therefore be safely employed in patients in whom marked circulatory changes should be avoided.

\section{RÉSUMÉ}

La Ketamine à la dose de $2.0 \mathrm{mgm} / \mathrm{kg}$, employée seule avec le protoxyde d'azote-oxygène en inhalation, produisit une élévation de la pression sanguine, de la fréquence cardiaque et des niveaux plasmatiques de nor-épinéphrine libre chez douze malades soumis à une chirurgie élective. Contrairement aux prévisions, l'association de Ketamine avec le Pancuronium durant l'inhalation de protoxyde d’azote-oxygène n’amena aucune élévation de nor-épinéphrine libre dans le plasma et diminua l'élévation de la tension artérielle et de la fréquence cardiaque. L'intubation, la préparation chirurgicale et les changements de posture étaient interdits. L'étude des gaz sanguins ne démontra aucune hypoxie ni hypercarbie. Le mécanisme de cet effet de blocage du Pancuronium sur l'élévation de nor-épinéphrine suscitée par la Ketamine doit attendre, pour trouver son explication, de plus amples essais en laboratoire et en clinique. L'association de la Ketamine avec le Pancuronium peut donc être utilisée avec sécurité chez les malades où l'on doit éviter des changements circulatoires marqués.

\section{ACKNOWLEDGMENTS}

We are grateful to Organon Inc. for their generous support of these investigations and to the Staff of the Department of Obstetrics and Gynaecology for their courtesy in obtaining permission from their patients for this study.

\section{REFERENCES}

1. Corssen, G. \& Domino, E.F. Dissociative anesthesia: further pharmacologic studies and first clinical experience with the phencyclidine derivative CI-581. Anesth. Analg. (Cleveland) 45: 29-40 (1966).

2. Zsigmond, E.K., Kelsch, R.C., Kothary, S.P., \& Vadnay, L. Free nor-epinephrine concentrations during induction of anesthesia with ketamine. Rev. Brasil, Anest. 22: 443451 (1972).

3. Saxena, P.R. \& Bonta, I.L. Specific blockade of cardiac muscarinic receptors by pancuronium bromide. Arch. Int. Pharmacodyn. 189: 410-412 (1971).

4. Kelman, G.R. \& Kennedy, B.R. Cardiovascular effects of pancuronium in men. Brit. J. Anaesth. 43: 335-338 (1971). 
5. Gertel, M., Fox, G.S., Rabow, F.I., \& Graham, D.H. The cardiovascular effects of pancuronium bromide during halothane anesthesia. Canad. Anaesth. Soc. J. I9: 599-606 (November 1972).

6. Zsigmond, E.K., Marsuki, A., Kothary, S.P., \& Kelsch, R.C. Pancuronium bromide on plasma catecholamine and cortisol concentrations during thiamylal induction. Canad. Anaesth. Soc. J., accepted for publication.

7. Matsukr, A., KothaRY, S.P., \& Zsigmond, E.K. Lack of compensatory increase in plasmafree nor-epinephrine during hypotension induced by intravenous thiamylal anesthesia. Der Anesthetist 22: 289-291 (1973).

8. Kelsch, R.C., Light, G.S., Luciano, J.R., \& Oliver, W.J. The effects of prednisone on plasma nor-epinephrine concentration and renin activity in salt-depleted men. J. Lab. Clin. Med. 77: 267-277 (1971).

9. Astrup, P., Jørgensen, K., SiggaAmd-Andersen, O., \& Engel, K. The acid-base metabolism, a new approach. Lancet 1: 1035-1039 (1960).

10. Vintue, R.W. et al. An anesthetic agent: 2-orthochlorophenyl, 2-methylamino cyclohexanone (CI-581). Anesthesiol 28: 823-833 (1967).

11. Kreuscher, H. \& GaUch, H. Analytical circulation studies with ketamine application in men, in Kreuscher, H.: Anesthesiology and resuscitation, 40: Ketamine. New York: Springer-Verlag, 52-57 (1969).

12. Traber, D.L. \& WILson, R.D. Involvement of the sympathetic nervous system in the pressor response to ketamine. Anesth. Analg. (Cleveland) 48: 248-252 (1969). 